\title{
BK polyomavirus association with colorectal cancer development
}

\author{
M.N. Khabaz', T. Nedjadi' ${ }^{2}$ M.A. Gari ${ }^{3}$, J.A. Al-Maghrabi ${ }^{4}$, H.M. Atta ${ }^{5,6}$, \\ A.A. Basuni ${ }^{5,7}$ and D.A. Elderwi ${ }^{8,9}$ \\ ${ }^{1}$ Department of Pathology, Faculty of Medicine, Rabigh Branch, \\ King Abdulaziz University, Jeddah, Saudi Arabia \\ ${ }^{2}$ King Fahd Medical Research Centre, King Abdulaziz University, Jeddah, \\ Saudi Arabia \\ ${ }^{3}$ Centre of Excellence in Genomic Medicine Research, \\ King Abdulaziz University, Jeddah, Saudi Arabia \\ ${ }^{4}$ Department of Pathology, Faculty of Medicine, King Abdulaziz University, \\ Jeddah, Saudi Arabia \\ ${ }^{5}$ Department of Clinical Biochemistry, Faculty of Medicine, Rabigh Branch, \\ King Abdulaziz University, Jeddah, Saudi Arabia \\ ${ }^{6}$ Department of Medical Biochemistry, Faculty of Medicine, Cairo University, \\ Cairo, Egypt \\ ${ }^{7}$ Liver Institute, Menoufia University, Al-Minufiya, Egypt \\ ${ }^{8}$ Department of Pediatric Dentistry, Faculty of Dentistry, \\ King Abdulaziz University, Jeddah, Saudi Arabia \\ ${ }^{9}$ Department of Public Health and Community Medicine, Faculty of Medicine, \\ Cairo University, Cairo, Egypt \\ Corresponding author: M.N. Khabaz \\ E-mail: mnkhabaz@kau.edu.sa/nkhabaz@yahoo.co.uk
}

Genet. Mol. Res. 15 (2): gmr.15027841

Received October 19, 2015

Accepted December 22, 2015

Published May 6, 2016

DOI http://dx.doi.org/10.4238/gmr.15027841

ABSTRACT. The development of human neoplasms can be provoked by exposure to one of several viruses. Burkitt lymphoma, cervical carcinoma, and hepatocellular carcinoma are associated with EpsteinBarr, human papilloma, and hepatitis B virus infections, respectively. 
Over the past three decades, many studies have attempted to establish an association between colorectal cancer and viruses, with debatable results. The aim of the present research was to assess the presence of BK polyomavirus (BKV) DNA and protein in colorectal cancer samples from patients in the Western Province of Saudi Arabia. DNA extracted from archival samples of colorectal cancer tissues was analyzed for BKV sequences using polymerase chain reaction (PCR)-based techniques. In addition, expression of a BKV protein was assessed using immunohistochemical staining. None of the tumor and control samples examined tested positive for BKV DNA in PCR assays. Furthermore, immunohistochemical staining failed to detect viral proteins in both cancer and control specimens. These results may indicate that BKV is not associated with the development of colorectal adenocarcinoma in patients in the Western Province of Saudi Arabia.

Key words: Colorectal cancer; BK polyomavirus; BKV

\section{INTRODUCTION}

BK polyomavirus (BKV) belongs to the Polyomaviridae family and bears close similarity to JC virus and Simian virus 40 in its ubiquity in mankind. BKV infection is common among humans and usually occurs in childhood, with more than $70 \%$ of people showing serological confirmation of exposure (Knowles et al., 2003). BKV was first identified in urine from a kidney transplant patient (Gardner et al., 1971), and has been described as a tumor virus due to its oncogenic activity in vitro and in animal models. Several research groups have drawn attention to the high tumorigenic potential of BKV. For instance, it is able to transform rodent cells into malignant neoplasm, and eternalize human cells alone or in combination with other oncogene families including myc and ras (Portolani et al., 1975; Grossi et al., 1982; Pagnani et al., 1988; Kenan et al., 2015). BKV inoculation into animal models causes the development of various neoplasms, including glioma, neuroblastoma, ependymoma, osteosarcoma, liposarcoma, and fibrosarcoma, among others (Tognon et al., 2003). The oncogenic potential of BKV is related to the influential transforming genes involved in growth control and mitogenic signaling encoded in its genome (Khalili et al., 2003; White and Khalili, 2004; Kenan et al., 2015).

BKV is a non-enveloped DNA virus with an icosahedral capsid containing a globular, double-stranded genome incorporating early- and late-transcription regions (Imperiale, 2000). The proteins VP1, VP2, VP3, and agnoprotein are encoded by the late region, while the early region codes for two tumor antigens, named the large $\mathrm{T}$ and small $\mathrm{t}$ antigens. The former interacts with $\mathrm{p} 53$ and $\mathrm{pRb}$ proteins, manipulating the cell cycle and provoking malignancy (Bollag et al., 1989; White and Khalili, 2004; Kenan et al., 2015). The binding of viral proteins to $\mathrm{pRb}$ causes the release E2F transcription factor, consequently increasing the expression of p14ARF, thus leading to the stabilization of p53 and suppression of its apoptotic functions, and halting the stimulation of cellular cyclin inhibitors. This process is essential to provide the ideal cellular conditions for viral replication and packaging, and enables nonpermissive cell transformation (Levine, 1997; Vogelstein et al., 2000; Damania, 2007).

Over recent decades, an increasing number of investigations have attempted to 
establish the involvement of the BKV genome and its protein products in human neoplasms. In spite of these numerous studies, the mechanistic role of BKV in human malignancies remains highly debatable. BKV DNA and proteins have been found in renal, bladder, prostate, pancreatic, adrenal, and brain cancer tissues (Corallini et al., 1987; Flaegstad et al., 1999; Fioriti et al., 2005; Barzon et al., 2008; Taghavi et al., 2015; Yin et al., 2015). On the other hand, several reports have failed to detect BKV in similar tumors (Arthur et al., 1994; Weggen et al., 2000; Knöll et al., 2003; Fischetti et al., 2004). The present study represents the first attempt to assess the presence of BKV DNA and proteins in colorectal cancer patients in the Western Province of Saudi Arabia.

\section{MATERIAL AND METHODS}

The current study used 83 paraffin-embedded tissue blocks from previously diagnosed colorectal cancers stored in the archive of the Pathology Department of King Abdulaziz University, Jeddah, Saudi Arabia, and 35 control samples from tumor-free colorectal tissues. Clinicopathological data including gender, age, cancer type, tumor size and anatomical site, and modified Dukes' grade were collected. Familial colorectal cancer cases or those having received radiation therapy or chemotherapy were excluded. Control samples were collected from individuals with noncancerous conditions (such as adenoma or polyps), as well as adjacent normal tissue and remote surgical margins. These control cases included 15 women and 20 men, with a mean age of 56.7 years, ranging from 28 to 87 years. All tumor and control tissue blocks were serially sectioned for use in the current study.

\section{Immunohistochemistry (IHC)}

Mouse monoclonal antibody against BKV (Chemicon International, Temecula, CA, USA) was utilized in a standard IHC staining protocol, as described by Khabaz (2013). Positive and negative controls were included, following the manufacturer protocol. Neoplasms were considered BKV-positive if more than $1 \%$ of the transformed cells demonstrated a distinct positive nuclear stain.

\section{DNA extraction}

A QIAamp DNA FFPE Kit (Qiagen, Hilden, Germany) was used to extract genomic DNA from paraffin-embedded tissue samples following the manufacturer protocol. DNA was eluted in $50 \mu$ L elution buffer and stored at $-40^{\circ} \mathrm{C}$ until use. A NanoDrop 2000 spectrophotometer (Thermo Scientific, Waltham, MA, USA) was used to analyze the purity and concentration of isolated DNA.

\section{Real-time polymerase chain reaction (PCR)}

A commercially available kit (Euro RT-BKV - cod. 9153; Eurospital, Trieste, Italy) was used to assess the presence or absence of BKV DNA in colorectal cancer and control tissues. DNA amplification was performed using a real-time thermocycler (One Shot; Applied Biosystems, Foster City, CA, USA) following the manufacturer instruction manual. $\beta$-globin was used as an internal control. 


\section{Statistical analysis}

Data were analyzed using SPSS version 21 (IBM, Armonk, NY, USA). Relationships between categorical variables were established by the chi-square test. $\mathrm{P}$ values $<0.05$ were considered statistically significant.

\section{RESULTS}

The tumors under investigation derived from the ascending colon $(21.69 \%)$, sigmoid colon $(20.48 \%)$, rectum $(18.08 \%)$, descending colon $(15.66 \%)$, and rectosigmoid colon (14.45\%). The transverse colon and cecum were each the site of $4.82 \%$ of the malignancies examined (Table 1). Almost 39\% of the tumors were well differentiated, with 48.2 and $13.25 \%$ being moderately and poorly differentiated, respectively (Table 1 ). In regard to modified Dukes' grading, 1.2, 2.4, 55.5, 34.9, and $6 \%$ of colorectal carcinoma cases were classified as A, B1, B2, C2, and D, respectively. The average cancer patient age was $57.8 \pm 12.8$ years, with women being slightly overrepresented. The frequencies at which malignancies occurred in each anatomical site were similar in both genders, with the exception of rectal tumors, for which men showed a higher incidence. Moderately differentiated tumors were more frequent among men $(52.6 \%)$ than women $(44.4 \%)$, while poorly differentiated tumors, especially with mucinous or signet-ring cell differentiation, were observed predominantly in female patients. Higher modified Dukes' grades were recorded mainly for colorectal carcinomas of male patients; 47.4 and $42.1 \%$ of cancers affecting the male study population were classified as C2 and B2, respectively, while almost $67 \%$ of tumors among women were graded B2 (Table 1). Lymph node involvement was found in almost $39 \%$ of cases. Nevertheless, none of the differences in clinical data between male and female study groups were statistically significant.

Table 1. Clinicopathological characteristics of colorectal cancer patients.

\begin{tabular}{|c|c|c|c|c|c|c|c|}
\hline \multirow{2}{*}{\multicolumn{2}{|c|}{ Characteristic }} & \multirow{2}{*}{\multicolumn{2}{|c|}{ All patients }} & \multirow{2}{*}{\multicolumn{2}{|c|}{ Female }} & \multirow{2}{*}{\multicolumn{2}{|c|}{ Male }} \\
\hline & & & & & & & \\
\hline Total & & $\begin{array}{c}\mathrm{N} \\
83\end{array}$ & $\%$ & $\begin{array}{c}\mathrm{N} \\
45\end{array}$ & $\begin{array}{c}\% \\
54.2\end{array}$ & $\begin{array}{c}\mathrm{N} \\
38\end{array}$ & $\begin{array}{c}\% \\
45.8\end{array}$ \\
\hline \multirow[t]{7}{*}{ Tumor location } & Ascending colon & 18 & 21.69 & 11 & 24.4 & 7 & 18.4 \\
\hline & Transverse colon & 4 & 4.82 & 3 & 6.6 & 1 & 2.6 \\
\hline & Descending colon & 13 & 15.66 & 7 & 15.5 & 6 & 15.78 \\
\hline & Rectum & 15 & 18.08 & 6 & 13.3 & 9 & 23.68 \\
\hline & Rectosigmoid colon & 12 & 14.45 & 7 & 15.5 & 5 & 13.15 \\
\hline & Sigmoid colon & 17 & 20.48 & 9 & 20 & 8 & 21.05 \\
\hline & Cecum & 4 & 4.82 & 2 & 4.4 & 2 & 5.26 \\
\hline \multirow[t]{3}{*}{ Tumor differentiation } & Well, with or without mucinous differentiation & 32 & 38.55 & 17 & 37.8 & 15 & 39.4 \\
\hline & Moderate, with or without mucinous differentiation & 40 & 48.2 & 20 & 44.4 & 20 & 52.6 \\
\hline & Poor, with or without mucinous or signet-ring cell differentiation & 11 & 13.25 & 8 & 17.8 & 3 & 7.9 \\
\hline \multirow[t]{5}{*}{ Dukes' grade } & A & 1 & 1.2 & 0 & 0 & 1 & 2.6 \\
\hline & B1 & 2 & 2.4 & 0 & 0 & 2 & 5.3 \\
\hline & B2 & 46 & 55.5 & 30 & 66.7 & 16 & 42.1 \\
\hline & C2 & 29 & 34.9 & 11 & 24.4 & 18 & 47.4 \\
\hline & D & 5 & 6 & 4 & 8.9 & 1 & 2.6 \\
\hline
\end{tabular}

PCR assays revealed all examined colorectal carcinoma cases and controls to be negative for BKV DNA. Furthermore, IHC staining using a specific anti-BKV antibody failed to detect viral proteins in both tumor and control samples, indicating that BKV protein is not expressed in colorectal carcinoma tissues. 


\section{DISCUSSION}

Many viruses have been put forward as possible carcinogenic agents, but their specific roles in the occurrence of human malignant neoplasms remain to be conclusively established. Owing to satisfactory evidence from animal models but insufficient confirmation in human beings, the Monograph Working Group of the World Health Organization International Agency for Cancer Research has recently categorized JC virus, Simian virus 40, and BKV as "possibly carcinogenic to humans" (Group 2B; Bouvard et al., 2012). This particularly applies to the relationship between BKV and colorectal cancer, as over the last decade, an association between this virus and the development of this disease has been reported. To our knowledge, six studies have investigated the carcinogenic role of BKV in human colorectal cancer to date. Of these, only two research groups detected BKV DNA and proteins in colorectal adenocarcinoma tissue (Casini et al., 2005; Giuliani et al., 2008). The PCR and IHC techniques employed in the current study failed to detect genetic material and protein deriving from the virus under investigation in colorectal carcinoma and control tissues. Our data are consistent with the findings of four other research teams who found no evidence of BKV DNA in a large range of colorectal cancer, adenoma, and normal mucosa samples (Militello et al., 2009; Campello et al., 2010; Fiorina et al., 2014; Ripple et al., 2014). Such contradictions may be explained by false-positive results due to contamination during experimental procedures, the sensitivity of the protocols used, population diversity and sample size variation, and BKV incidence in the geographical area of study. Another possible explanation involves the loss of BKV DNA and protein. This could be explained by an incompatibility between the growth of cells during the later stages of carcinogenesis and the ability of BKV tumor antigen to induce chromosomal damage and apoptotic effects (Theile and Grabowski, 1990; Tognon et al., 1996; Trabanelli et al., 1998). Absence of viral DNA may result from the dilution of episomal DNA or immune system selection against viral tumor antigen proteins. Alternatively, a "hit and run" mechanism may account for the loss of BKV in human colorectal cancer tissues (Tognon et al., 2003).

\section{CONCLUSION}

The current study failed to detect BKV in the colorectal carcinoma samples tested. Accordingly, this report provides no evidence to support a significant role for BKV in colorectal carcinogenesis among patients in the western Province of Saudi Arabia. We recommend that new DNA detection methods should be utilized to further investigate the role of this virus in colorectal cancer.

\section{Conflicts of interest}

The authors declare no conflict of interest.

\section{ACKNOWLEDGMENTS}

Research supported by the National Plan for Science, Technology and Innovation (MAARIFAH), King Abdulaziz City for Science and Technology, the Kingdom of Saudi Arabia (\#11-MED2034-03). The authors also acknowledge with thanks the Science and Technology Unit, King Abdulaziz University, for their technical support. 


\section{REFERENCES}

Arthur RR, Grossman SA, Ronnett BM, Bigner SH, et al. (1994). Lack of association of human polyomaviruses with human brain tumors. J. Neurooncol. 20: 55-58.http://dx.doi.org/10.1007/BF01057961

Barzon L, Trevisan M, Masi G, Pacenti M, et al. (2008). Detection of polyomaviruses and herpesviruses in human adrenal tumors. Oncogene 27: 857-864.http://dx.doi.org/10.1038/sj.onc.1210699

Bollag B, Chuke WF and Frisque RJ (1989). Hybrid genomes of the polyomaviruses JC virus, BK virus, and simian virus 40: identification of sequences important for efficient transformation. J. Virol. 63: 863-872.

Bouvard V, Baan RA, Grosse Y, Lauby-Secretan B, et al.; WHO International Agency for Research on Cancer Monograph Working Group (2012). Carcinogenicity of malaria and of some polyomaviruses. Lancet Oncol. 13: 339-340.http:// dx.doi.org/10.1016/S1470-2045(12)70125-0

Campello C, Comar M, Zanotta N, Minicozzi A, et al. (2010). Detection of SV40 in colon cancer: a molecular case-control study from northeast Italy. J. Med. Virol. 82: 1197-1200.http://dx.doi.org/10.1002/jmv.21798

Casini B, Borgese L, Del Nonno F, Galati G, et al. (2005). Presence and incidence of DNA sequences of human polyomaviruses BKV and JCV in colorectal tumor tissues. Anticancer Res. 25 (2A): 1079-1085.

Corallini A, Pagnani M, Viadana P, Silini E, et al. (1987). Association of BK virus with human brain tumors and tumors of pancreatic islets. Int. J. Cancer 39: 60-67.http://dx.doi.org/10.1002/ijc.2910390111

Damania B (2007). DNA tumor viruses and human cancer. Trends Microbiol. 15: 38-44.http://dx.doi.org/10.1016/j. tim.2006.11.002

Fiorina L, Ricotti M, Vanoli A, Luinetti O, et al. (2014). Systematic analysis of human oncogenic viruses in colon cancer revealed EBV latency in lymphoid infiltrates. Infect. Agent. Cancer 9: 18.http://dx.doi.org/10.1186/1750-9378-9-18

Fioriti D, Videtta M, Mischitelli M, Degener AM, et al. (2005). The human polyomavirus BK: Potential role in cancer. $J$. Cell. Physiol. 204: 402-406.http://dx.doi.org/10.1002/jcp.20300

Fischetti G, Leone P, Barrese F, Curari S, et al. (2004). Role of viral infection in the aetiology-pathogenesis of bladder tumor: a reality or chimera? Eur. J. Inflamm. 2: 33-38.

Flaegstad T, Andresen PA, Johnsen JI, Asomani SK, et al. (1999). A possible contributory role of BK virus infection in neuroblastoma development. Cancer Res. 59: 1160-1163.

Gardner SD, Field AM, Coleman DV and Hulme B (1971). New human papovavirus (B.K.) isolated from urine after renal transplantation. Lancet 1: 1253-1257.http://dx.doi.org/10.1016/S0140-6736(71)91776-4

Giuliani L, Ronci C, Bonifacio D, Di Bonito L, et al. (2008). Detection of oncogenic DNA viruses in colorectal cancer. Anticancer Res. 28 (2B): 1405-1410.

Grossi MP, Corallini A, Valieri A, Balboni PG, et al. (1982). Transformation of hamster kidney cells by fragments of BK virus DNA. J. Virol. 41: 319-325.

Imperiale MJ (2000). The human polyomaviruses, BKV and JCV: molecular pathogenesis of acute disease and potential role in cancer. Virology 267: 1-7.http://dx.doi.org/10.1006/viro.1999.0092

Kenan DJ, Mieczkowski PA, Burger-Calderon R, Singh HK, et al. (2015). The oncogenic potential of BK-polyomavirus is linked to viral integration into the human genome. J. Pathol. 237: 379-389.http://dx.doi.org/10.1002/path.4584

Khabaz MN (2013). Association of Epstein-Barr virus infection and breast carcinoma. Arch. Med. Sci. 9: 745-751.http:// dx.doi.org/10.5114/aoms.2013.37274

Khalili K, Del Valle L, Otte J, Weaver M, et al. (2003). Human neurotropic polyomavirus, JCV, and its role in carcinogenesis. Oncogene 22: 5181-5191.http://dx.doi.org/10.1038/sj.onc.1206559

Knöll A, Stoehr R, Jilg W and Hartmann A (2003). Low frequency of human polyomavirus BKV and JCV DNA in urothelial carcinomas of the renal pelvis and renal cell carcinomas. Oncol. Rep. 10: 487-491.

Knowles WA, Pipkin P, Andrews N, Vyse A, et al. (2003). Population-based study of antibody to the human polyomaviruses BKV and JCV and the simian polyomavirus SV40. J. Med. Virol. 71: 115-123.http://dx.doi.org/10.1002/jmv.10450

Levine AJ (1997). p53, the cellular gatekeeper for growth and division. Cell 88: 323-331.http://dx.doi.org/10.1016/S0092$\underline{8674(00) 81871-1}$

Militello V, Trevisan M, Squarzon L, Biasolo MA, et al. (2009). Investigation on the presence of polyomavirus, herpesvirus, and papillomavirus sequences in colorectal neoplasms and their association with cancer. Int. J. Cancer 124: 2501-2503.http://dx.doi.org/10.1002/ijc.24224

Pagnani M, Corallini A, Caputo A, Altavilla G, et al. (1988). Co-operation in cell transformation between BK virus and the human c-Harvey-ras oncogene. Int. J. Cancer 42: 405-413.http://dx.doi.org/10.1002/ijc.2910420317

Portolani M, Barbanti-Brodano G and Placa ML (1975). Malignant transformation of hamster kidney cells by BK virus. J. Virol. 15: 420-422.

Ripple MJ, Parker Struckhoff A, Trillo-Tinoco J, Li L, et al. (2014). Activation of c-Myc and Cyclin D1 by JCV T-Antigen and $\beta$-catenin in colon cancer. PLoS One 9: e106257.http://dx.doi.org/10.1371/journal.pone.0106257 
Taghavi A, Mohammadi-Torbati P, Kashi AH, Rezaee H, et al. (2015). Polyomavirus Hominis 1(BK virus) Infection in Prostatic Tissues: Cancer versus Hyperplasia. Urol. J. 12: 2240-2244.

Theile M and Grabowski G (1990). Mutagenic activity of BKV and JCV in human and other mammalian cells. Arch. Virol. 113: 221-233.http://dx.doi.org/10.1007/BF01316675

Tognon M, Casalone R, Martini F, De Mattei M, et al. (1996). Large T antigen coding sequences of two DNA tumor viruses, BK and SV40, and nonrandom chromosome changes in two glioblastoma cell lines. Cancer Genet. Cytogenet. 90: 17-23.http://dx.doi.org/10.1016/0165-4608(96)00067-2

Tognon M, Corallini A, Martini F, Negrini M, et al. (2003). Oncogenic transformation by BK virus and association with human tumors. Oncogene 22: 5192-5200.http://dx.doi.org/10.1038/sj.onc. 1206550

Trabanelli C, Corallini A, Gruppioni R, Sensi A, et al. (1998). Chromosomal aberrations induced by BK virus T antigen in human fibroblasts. Virology 243: 492-496.http://dx.doi.org/10.1006/viro.1998.9080

Vogelstein B, Lane D and Levine AJ (2000). Surfing the p53 network. Nature 408: 307-310.http://dx.doi. org $/ 10.1038 / 35042675$

Weggen S, Bayer TA, von Deimling A, Reifenberger G, et al. (2000). Low frequency of SV40, JC and BK polyomavirus sequences in human medulloblastomas, meningiomas and ependymomas. Brain Pathol. 10: 85-92.http://dx.doi. org/10.1111/j.1750-3639.2000.tb00245.x

White MK and Khalili K (2004). Polyomaviruses and human cancer: molecular mechanisms underlying patterns of tumorigenesis. Virology 324: 1-16.http://dx.doi.org/10.1016/j.virol.2004.03.025

Yin WY, Lee MC, Lai NS and Lu MC (2015). BK virus as a potential oncovirus for bladder cancer in a renal transplant patient. J. Formos. Med. Assoc. 114: 373-374.http://dx.doi.org/10.1016/j.jfma.2012.02.019 